\title{
Management of Brown-Sequard Syndrome in Cervical Disc Diseases
}

\section{Servikal Disk Hastallklarında Brown-Sequard Sendromunun Takibi}

\author{
Safwat ABOUHASHEM, Mohamad AMMAR, Mohamad BARAKAT, Essam ABDELHAMEED \\ Zagazig University, Faculty of Medicine, Department of Neurosurgery, Zagazig, Sharkia, Egypt
}

Corresponding Author: Safwat ABOUHASHEM / E-mail: drsam1974@gmail.com

\begin{abstract}
AIM: To raise the awareness of the appropriate management of unusual clinical presentation of cervical disc herniation.

MATERIAL and METHODS: Seven patients with Brown-Sequard syndrome due to cervical disc herniation presented with Brown-Sequard syndrome had been treated surgically as one of them treated with anterior cervical discectomy and three patients treated by anterior cervical discectomy and fusion while three of them have been treated by posterior laminectomy.

RESULTS: Patients were 7 three of them were female and four were males and the mean age of our patients is $45.28 \pm 16.49$ years ranged between 32 and 72 years. History of spinodegenerative disease in the form of chronic neck pain with or without brachialgia was found in $6 / 7$ patients (85.7\%) while history of trauma was found in 5/7 patients (71.4\%). Most common affected level is C5-C6 disc Outcome after surgical treatment revealed complete recovery in $4 / 7$ patients $(57.1 \%)$ while incomplete recovery in 2 patients $(28.6 \%)$ and no improvement in one patient (14.3\%).
\end{abstract}

CONCLUSION: Brown-Sequard syndrome is a rare presentation of cervical disc herniation but accurate diagnosis, and early anterior spinal cord decompression lead to complete recovery of these cases.

KEYWORDS: Cervical disc, Herniation, Brown-Sequard, Management

öz

AMAÇ: Servikal disk herniasyonunun olağandışı klinik sunumunun uygun takibi konusunda farkındalığı arttırmak.

YÖNTEM ve GEREÇLER: Servikal disk herniasyonu nedeniyle Brown-Sequard sendromu olan 7 hasta cerrahi olarak tedavi edildi. Bunların biri anterior diskektomi ile, üç hasta anterior servikal diskektomi ve füzyonla ve üç hasta posterior laminektomiyle tedavi edildi.

BULGULAR: 7 hastanın üçü kadın ve dördü erkekti ve ortalama yaş 32 ile 72 aralığında olup 45,28 16,49 yıldı. Brakialji ile veya olmadan kronik boyun ağrısı şeklinde spinodejeneratif hastalık öyküsü 6/7 hastada mevcuttu $(\% 85,7)$ ve travma öyküsü $5 / 7$ hastada bulundu (\%71,4). En sık etkilenen seviye C5-C6 diskti. Cerrahi tedaviden sonra 4/7 hastada tam iyileşme (\%57,1), 2 hastada tam olmayan iyileşme (\%28,6) oldu ve 1 hastada $(\% 14,3)$ iyileşme olmadı.

SONUÇ: Brown-Sequard sendromu servikal disk herniasyonunun nadir bir sunumudur ama erken tanı ve erken anterior spinal kord dekompresyonu bu olgularda tam iyileşme sağlar.

ANAHTAR SÖZCÜKLER: Servikal disk, Herniasyon, Brown-Sequard, Takip

\section{INTRODUCTION}

Cervical disc herniation is a common neurosurgical problem and Those patient who suffered from cervical disc disease may be presented with neck pain, cervical radiculopathy, myelopathy or radiculomylopathy and although the herniated disc usually symptomatize the ipsilateral side (28) there are rare reported cases with contralateral symptoms in the form of complete or incomplete Brown-Sequard syndrome $(2,14,16,20,28)$ which is a neurological syndrome due to an incomplete spinal cord compression with ipsilateral motor deficit, loss of proprioception, and vibratory sensation with contralateral loss of pain and temperature $(3,11,26)$.

The syndrome was first reported in 1849 in a case of spinal cord injury by a knife (4) but later on Brown-Sequard syn- drome has been commonly reported in patients with spinal trauma or in patients with spinal neoplasm, and in rare cases due to cervical disc herniation which was considered an exceptional cause of this syndrome $(11,23)$.

According to our knowledge there are 42 cases have been reported in the English language literature up to now with Brown-Sequard syndrome due to cervical disc herniation (3, $14,20,27,28,29$ ).

Cervical disc herniation can be managed using conservative measures which involve the medical treatment, physiotherapy and rehabilitation but surgical treatment has the superiority in cases with progressive neurological deficit or failure of conservative treatment. 
There are several surgical options for cervical disc disease which include the anterior cervical discectomy with or without fusion, posterior lamino foraminotomy or posterior laminectomy.

\section{PATIENTS and METHODS}

During our clinical practice in the last ten years we reported seven patients with Brown-Sequard syndrome due to cervical disc herniation. Three of them were female and four were male their age was ranged between 32 and 72 years with mean age $45.28 \pm 16.49$ years (Table II).

All patients presented with unilateral motor deficit involving the upper and lower limb. Detailed history revealed prolonged history of spinodegenerative disease in the form of chronic neck pain with or without brachialgia in 6 patients and the course started to be rapidly progressing over days in all of them and was preceeded by mild trauma (carrying heavy object on the head or slipped down stairs) in five patients.

Detailed clinical examination of the patient showed unilateral motor weakness with contra lateral sensory deficit but without loss of deep sensation.

MRI had been done for all patients who revealed cervical cord compression where single level disease was found in 4 patients and double level in one patient and multiple levels was found in two patients.

All patients had been treated surgically as one of them treated with anterior cervical discectomy and three patients treated by anterior cervical discectomy and fusion while three of them have been treated by posterior laminectomy with discectomy in two of them and without discectomy in the last one. The mean time of symptoms duration before intervention was $14 \pm 9.26$ days.

Three-month postoperative follow-up showed complete recovery in 4 patients and incomplete recovery in two patients while there was no neurological improvement in only one case.

\section{RESULTS}

Of our 7 patients, three were female and four were male and the mean age of our patients was $45.28 \pm 16.49$ years, ranging between 32 and 72 years. History of spinodegenerative disease in the form of chronic neck pain with or without brachialgia was found in $6 / 7$ patients (85.7\%) while history of trauma was found in $5 / 7$ patients $(71.4 \%)$. The most commonly affected level was the $\mathrm{C} 5-\mathrm{C} 6 \mathrm{disc}$.

Outcome after surgical treatment revealed complete recovery in $4 / 7$ patients $(57.1 \%)$ while there was incomplete recovery in 2 patients $(28.6 \%)$ and no improvement in one patient (14.3\%).

\section{DISCUSSION}

Cervical disc herniation is a common neurosurgical problem that is encountered in routine neurosurgical practice. These patients may present with neck pain, cervical radiculopathy, myelopathy or radiculomyelopathy. Although the herniated disc usually produces symptoms in the ipsilateral side (28), there are rare reported cases with contralateral symptoms in the form of complete or incomplete Brown-Sequard syndrome $(2,14,16,20,28)$. This is a rare neurological entity due to spinal cord compression leading to loss of motor function, deep sensation and crude touch on one side of the body due to compression of the corticospinal tract, gracile and cuneate tract respectively. These findings are associatedwith a loss of pain and temperature sensation in the opposite side as a result of spinothalamic tract dysfunction $(1,26)$.

Cervical disc herniation is a progressive disorder that typically presents with neck pain and ipsilateral radiculopathy due to compression or inflammatory process of the corresponding nerve root (28). When the contralateral side is affected, cord compression should be considered $(11,23,28)$.

In our series we reported seven cases that presented with unilateral motor deficit and contralateral sensory deficit due to cervical disc herniation. This number could be considered very small regarding our workflow at a university hospital where 5 million people come and more than three thousand patients a year are treated. This rarity of BSS due to cervical disc herniation is similar to the reported data in the literature because according to our knowledge there is only 45 cases with BSS due to cervical disc disease in the English language literature (Table I) $(3,14,20,27,28,29)$.

The mean age in our cases was $45.28 \pm 16.49$ years and ranged between 32 and 72 years. This is also similar to the age of the reported cases in the literature, as the mean age is $47.59 \pm 11.66$ years ranging between 25 and 73 years and this finding not far away from the study of Schoenfeld et al. (25) who reported that although the age of herniated cervical disc is less than 40 years but cervical degenerative disease is considered a natural aging process and usually affects people older than 40 years.

The male predominance of cervical radiculopathy due to all aetiology has been documented by Radhakrishnan et al. (17). Kelley (9) suggested that the male to female ratio for cervical disc herniation is approximately 1:1. (9) while Marchiori and Henderson (16) found that women have higher rates of disability with increasing levels of spinal degenerative disease than men. Schoenfeld et al. (25) found that female sex was a significant risk factor for developing cervical radiculopathy while in the reported cases in the literature with BBS there are 34 males (75.6\%) and 11 females (24.4\%). In our study three were female $(42.9 \%)$ and four were male $(57.1 \%)$ out of the 7 patients and this difference can be explained by the lifestyle of Egyptian women as there is lack of sport and most of females in our community carry bags on their head.

Complete or typical picture of Brown-Sequard syndrome is a rare finding $(13,14)$ and all our cases presented with incomplete Brown-Sequard syndrome (5/7) as there was no loss of deep sensation in any of them. This can be explained by presence of anterior compression which leads to affection 
Table I: Reported Cases in the Literature

\begin{tabular}{|c|c|c|c|c|c|c|c|c|c|c|}
\hline $\mathbf{N}$ & Reference & Age & $\operatorname{Sex}$ & Level & Duration & Location & Surgery & Recovery & MR & SR \\
\hline 1 & Stookey.,1928 (3) & 44 & M & $\mathrm{C} 3-\mathrm{C} 4$ & NR & ED & LAM & NR & $\begin{array}{c}\text { No } \\
\text { change }\end{array}$ & $\begin{array}{c}\text { No } \\
\text { change }\end{array}$ \\
\hline 2 & & 52 & M & C5-C6 & NR & ED & LAM & NR & $\begin{array}{c}\text { No } \\
\text { change }\end{array}$ & $\begin{array}{c}\text { No } \\
\text { change }\end{array}$ \\
\hline 3 & & 68 & M & C6-C7 & NR & ED & LAM & NR & $\begin{array}{c}\text { No } \\
\text { change }\end{array}$ & $\begin{array}{c}\text { No } \\
\text { change }\end{array}$ \\
\hline 4 & $\begin{array}{l}\text { Düerig and } \\
\text { Zdrojewski., } 1977 \text { (3) }\end{array}$ & 52 & M & $\mathrm{C} 5-\mathrm{C} 6$ & $2 \mathrm{M}$ & ID & LAM & INC & INC & C \\
\hline 5 & Roda et al., 1982 (18) & 43 & M & $\mathrm{C} 6-\mathrm{C} 7$ & $1 \mathrm{D}$ & ID & LAM & INC & INC & C \\
\hline 6 & $\begin{array}{l}\text { Eisenberg et al., } 1986 \\
\text { (5) }\end{array}$ & 25 & M & $\mathrm{C} 5-\mathrm{C} 6$ & $4 \mathrm{D}$ & ID & LAM & INC & INC & INC \\
\hline 7 & $\begin{array}{l}\text { Schneider et al., } \\
1988(24)\end{array}$ & 50 & $\mathrm{~F}$ & $\mathrm{C} 5-\mathrm{C} 6$ & $1 \mathrm{D}$ & ID & $A C D$ & INC & INC & INC \\
\hline 8 & Sprick et al., 1991 (3) & 49 & $\mathrm{~F}$ & $\mathrm{C6}-\mathrm{C} 7$ & $10, D$ & ID & ACDF & INC & INC & INC \\
\hline 9 & Fineli et al., 1992 (6) & 28 & $\mathrm{~F}$ & C5-C6 & $18 \mathrm{M}$ & ED & ACDF & NR & $\begin{array}{c}\text { No } \\
\text { change }\end{array}$ & $\begin{array}{c}\text { No } \\
\text { change }\end{array}$ \\
\hline 10 & & 61 & M & $\mathrm{C6}-\mathrm{C7}$ & $8 M$ & $\mathrm{ED}$ & ACD & $C R$ & CR & CR \\
\hline 11 & & 46 & $\mathrm{~F}$ & $\begin{array}{l}\mathrm{C} 4-\mathrm{C} 5 \\
\mathrm{C} 5-\mathrm{C} 6\end{array}$ & $18 \mathrm{M}$ & ED & $A C D$ & CR & $\mathrm{CR}$ & CR \\
\hline 12 & $\begin{array}{l}\text { Rumana and } \\
\text { Baskin.,1996 (19) }\end{array}$ & 56 & $\mathrm{~F}$ & $\mathrm{C} 4-\mathrm{C} 5$ & $5 \mathrm{M}$ & ED & ACDF & CR & $\mathrm{CR}$ & CR \\
\hline 13 & Antich et al.,1999 (1) & 73 & $\mathrm{~F}$ & $\mathrm{C} 2-\mathrm{C} 3$ & $6 \mathrm{M}$ & ED & ACDF & $\mathrm{CR}$ & CR & $\mathrm{CR}$ \\
\hline 14 & Kohno et al., 1999 (21) & 33 & M & $\mathrm{C} 4-\mathrm{C} 5$ & $1 \mathrm{M}$ & ED & ACDF & CR & $\mathrm{CR}$ & $\mathrm{CR}$ \\
\hline 15 & & 31 & M & $\mathrm{C} 5-\mathrm{C} 6$ & $3 M$ & ED & ACDF & INC & INC & INC \\
\hline 16 & & 38 & M & $\mathrm{C} 5-\mathrm{C} 6$ & $4 \mathrm{M}$ & ED & ACDF & INC & INC & INC \\
\hline 17 & & 34 & M & $\mathrm{C} 3-\mathrm{C} 4$ & $15 \mathrm{M}$ & ED & ACDF & INC & INC & INC \\
\hline 18 & & 45 & $\mathrm{~F}$ & $\begin{array}{l}\mathrm{C} 4-\mathrm{C} 5 \\
\mathrm{C} 5-\mathrm{C} 6\end{array}$ & $13 \mathrm{M}$ & ED & ACDF & INC & CR & INC \\
\hline 19 & $\begin{array}{l}\text { Börm and Bohnstedt., } \\
2000 \text { (2) }\end{array}$ & 40 & M & $\mathrm{C} 5-\mathrm{C} 6$ & $5 \mathrm{WK}$ & ID & ACDF & CR & CR & $\mathrm{CR}$ \\
\hline 20 & $\begin{array}{l}\text { Clatterbuck et al., } \\
2000 \text { (4) }\end{array}$ & 40 & M & C4-C5 & $5 \mathrm{WK}$ & ID & $A C D F+L A M$ & INC & INC & INC \\
\hline 21 & & 52 & $\mathrm{~F}$ & $\mathrm{C} 3-\mathrm{C} 4$ & $2 M$ & ID & ACDF & $\mathrm{CR}$ & CR & $\mathrm{CR}$ \\
\hline 22 & & 32 & M & $\mathrm{C} 5-\mathrm{C} 6$ & $9 W K$ & ID & ACF & CR & CR & CR \\
\hline 23 & $\begin{array}{l}\text { Iwamura et al., } 2001 \\
(8)\end{array}$ & 45 & M & $\mathrm{C} 6-\mathrm{C} 7$ & $15 \mathrm{M}$ & ID & $\mathrm{ACF}$ & INC & C & INC \\
\hline 24 & $\begin{array}{l}\text { Kobayashi et al., } 2003 \\
\text { (11) }\end{array}$ & 64 & M & $\mathrm{C} 5-\mathrm{C} 6$ & $6 \mathrm{M}$ & ED & ACDF & CR & CR & $\mathrm{CR}$ \\
\hline 25 & & 39 & M & $\mathrm{C} 2-\mathrm{C} 3$ & $1 \mathrm{M}$ & ED & ACDF & $\mathrm{CR}$ & CR & $\mathrm{CR}$ \\
\hline 26 & $\begin{array}{l}\text { Mastronardi and } \\
\text { Ruggeri, } 2004 \text { (16) }\end{array}$ & 36 & M & $\mathrm{C} 5-\mathrm{C} 6$ & $9 M$ & ED & ACDF & CR & CR & $\mathrm{CR}$ \\
\hline 27 & $\begin{array}{l}\text { Fujimato et al., } 2004 \\
\text { (7) }\end{array}$ & 54 & $M$ & C5-C6 & $3 M$ & ED & LAM & INC & INC & INC \\
\hline 28 & Sani et al., 2005, (22) & 44 & $\mathrm{~F}$ & C5-C6 & $6 \mathrm{WK}$ & ED & ACDF & CR & $C R$ & $\mathrm{CR}$ \\
\hline
\end{tabular}


Table I: Cont.

\begin{tabular}{|c|c|c|c|c|c|c|c|c|c|c|}
\hline 29 & Kim et al., 2005(3) & 56 & $M$ & $\mathrm{C} 5-\mathrm{C} 6$ & $2 M$ & ED & $\mathrm{AF}$ & $\mathrm{CR}$ & CR & CR \\
\hline 30 & & 46 & M & C5-C6 & $2 W K$ & ED & $\mathrm{AF}$ & $\mathrm{CR}$ & CR & CR \\
\hline 31 & Wang et al., 2006, (27) & 44 & M & $\mathrm{C} 3-\mathrm{C} 4$ & $45 \mathrm{D}$ & ED & ACDF & $\mathrm{CR}$ & CR & CR \\
\hline 32 & $\begin{array}{l}\text { Sathirapanya et al., } \\
2007 \text { (3) }\end{array}$ & 63 & M & $\mathrm{C} 5-\mathrm{C} 6$ & $8 \mathrm{D}$ & ED & ACDF & $\mathrm{CR}$ & CR & CR \\
\hline 33 & Lee et al.,2007(14) & 56 & M & $\mathrm{C} 5-\mathrm{C} 6$ & $8 d$ & ED & $\begin{array}{l}\text { Discectomy } \\
\text { and } \\
\text { foraminotomy }\end{array}$ & $\mathrm{CR}$ & CR & CR \\
\hline 34 & & 47 & M & $\mathrm{C} 5-\mathrm{C} 6$ & $2 w$ & ED & $\begin{array}{l}\text { Discectomy } \\
\text { and } \\
\text { foraminotomy }\end{array}$ & $\mathrm{CR}$ & CR & CR \\
\hline 35 & & 45 & M & C5-C6 & $2 m$ & ED & $\begin{array}{c}\text { Discectomy } \\
\text { and } \\
\text { foraminotomy }\end{array}$ & $\mathrm{CR}$ & CR & CR \\
\hline 36 & Sayer et al., 2008 [23] & 46 & $M$ & C3-C4 & $3 M$ & ED & ACDF & $\mathrm{CR}$ & CR & CR \\
\hline 37 & Choi et al., 2009 (3) & 31 & M & $\mathrm{C} 3-\mathrm{C} 4$ & $4 M$ & ED & ACDF & $\mathrm{CR}$ & CR & CR \\
\hline 38 & & 66 & $\mathrm{~F}$ & $\begin{array}{l}\text { C5-C6, } \\
\text { C6-C7 }\end{array}$ & $2 \mathrm{M}$ & ED & ACDF & $\mathrm{CR}$ & CR & CR \\
\hline 39 & & 66 & $M$ & C5-C6 & $4 M$ & ED & ACDF & INC & INC & INC \\
\hline 40 & & 46 & M & $\mathrm{C} 4-\mathrm{C} 5$ & $2 \mathrm{D}$ & ED & ACDF & INC & INC & INC \\
\hline 41 & & 50 & $\mathrm{~F}$ & $\begin{array}{l}\text { C3-C4, } \\
\text { C4-C5 }\end{array}$ & $3 \mathrm{M}$ & ED & ACDF & INC & INC & INC \\
\hline 42 & Kim et al., 2009(10) & 28 & M & C3-C4 & $1 \mathrm{~W}$ & ED & ACDF & $\mathrm{CR}$ & $C R$ & $C R$ \\
\hline 43 & $\begin{array}{l}\text { Rustagi et al., } \\
2011(20)\end{array}$ & 42 & M & $\begin{array}{l}\mathrm{C} 5-6 \\
\mathrm{C} 6-7\end{array}$ & $8 \mathrm{~m}$ & ED & ACDF & INC & INC & INC \\
\hline 44 & $\begin{array}{l}\text { Yokoyama et al., } \\
\text { 2012(29) }\end{array}$ & 63 & M & $\begin{array}{c}\text { C3-4 } \\
\text { stenosis }\end{array}$ & $4 d$ & ED & lam & $\mathrm{CR}$ & CR & CR \\
\hline 45 & Yeung et al., 2012(28) & 35 & M & C5-6 & NR & ED & ACDF & $\mathrm{CR}$ & $C R$ & $C R$ \\
\hline
\end{tabular}

of the anteriorly located tracts such as the spinothalamic tract and corticospinal tract while sparing the posteriorly located gracile and cuneate tracts that carry the deep sensation and crude touch. The degree of motor deficit or sensory changes are not the same between the upper and lower limb and this finding is similar to most of the cases in the literature as typical BBS is seldom reported $(16,20)$.

A single traumatic event rarely leads to cervical disc herniation (28) but there was history of mild trauma in most of our cases $(5 / 7)$ in the form of carrying a heavy object on the head or wrong position and sleeping in a moving car. These were also was found in some of the reported cases in the Kobayashi et al. (11) report.

Intradural disc herniation is a very rare pathology and represents $0.3 \%$ of all disc herniations (2). In our cases, MRI findings showed intradural disc in only one case (14.7\%), which was single level and treated by posterior laminectomy and transdural discectomy. Another patient had extradural disc herniation. In the reported cases in the literature there was $10 / 45$ cases with intradural disc (22.2\%). This finding in our cases and in the reported cases may indicate significant suspicion of intradural disc rupture if a patient presents with BBS.

In our cases we reported history of neck pain with or without brachialgia due to cervical disc disease in $6 / 7$ of our patients before the onset of motor weakness that had been precipitated by mild unexpected or unnoticed trauma. This was also present in 21 out of 39 reported cases (20).

In our cases the C5-6 level has been involved in 6/7 in three patients it was the only pathology while it was associated with other levels in the other three cases but the C4-5 level involved in 3 cases and was the only pathology in one of them while C6-7 was involved in three cases but not the only pathology in any case and this finding is correlated with the incidence of cervical disc disease in the literature as the most common involved level is $\mathrm{C} 5-\mathrm{C} 6$ and this also have been found in the reported cases with BSS as there were 25 cases out of 45 cases but it was the only pathology in 21 cases $(3,14,20,27,28,29)$. 
Table II: Summary of the Cases in the Study

\begin{tabular}{|c|c|c|c|c|c|c|c|c|c|c|c|}
\hline Case & Age & Sex & $\begin{array}{c}\text { History } \\
\text { of } \\
\text { Trauma }\end{array}$ & $\begin{array}{l}\text { History of } \\
\text { cervical } \\
\text { spine } \\
\text { disease }\end{array}$ & $\begin{array}{l}\text { Clinical } \\
\text { finding }\end{array}$ & Level & $\begin{array}{c}\text { Duration } \\
\text { of } \\
\text { symptoms }\end{array}$ & Management & MR & SR & Outcome \\
\hline 1 & 23 & $\mathrm{~F}$ & Yes & Yes & $\begin{array}{l}\text { Incomplete } \\
\text { BSS }\end{array}$ & $C 4-5$ & 2 days & ACDF & CR & CR & CR \\
\hline 2 & 56 & $M$ & yes & Yes & $\begin{array}{c}\text { Incomplete } \\
\text { BSS }\end{array}$ & $\begin{array}{l}\text { C5-6, } \\
\text { C6-7 }\end{array}$ & 14 days & ACDF & CR & CR & CR \\
\hline 3 & 47 & $\mathrm{~F}$ & Yes & NO & $\begin{array}{c}\text { Incomplete } \\
\text { BSS }\end{array}$ & C5-6 & 7 days & $\begin{array}{c}\text { Laminectomy } \\
\text { and } \\
\text { discectomy }\end{array}$ & $C R$ & $C R$ & CR \\
\hline 4 & 37 & $\mathrm{~F}$ & No & Yes & $\begin{array}{c}\text { Incomplete } \\
\text { BSS }\end{array}$ & C5-6 & 21 day & $\begin{array}{l}\text { Laminectomy } \\
\text { and } \\
\text { discectomy }\end{array}$ & CR & INC R & INC R \\
\hline 5 & 72 & $M$ & Yes & Yes & $\begin{array}{l}\text { Incomplete } \\
\text { BSS }\end{array}$ & Multiple & 30 day & Laminectomy & $\begin{array}{c}\text { No } \\
\text { change }\end{array}$ & $\begin{array}{c}\text { No } \\
\text { change }\end{array}$ & $\begin{array}{c}\text { No } \\
\text { change }\end{array}$ \\
\hline 6 & 51 & $M$ & Yes & Yes & $\begin{array}{l}\text { Incomplete } \\
\text { BSS }\end{array}$ & Multiple & 10 day & ACDF & INC R & INC R & INC R \\
\hline 7 & 31 & $M$ & no & Yes & $\begin{array}{l}\text { Incomplete } \\
\text { BSS }\end{array}$ & $C 5-6$ & 14 day & $A C D$ & CR & $C R$ & CR \\
\hline
\end{tabular}

In our study no significant differences between the number of the diseased disc and clinical picture was present. There were 4 cases with a single level while one case was double level and 2 cases more than two levels.

In our series all patients showed a rapid progressive course of weakness with contralateral sensory loss over less than one week but the time of intervention was variable depending on the time of diagnosis with a mean time of intervention of 14 \pm 9.26 days.

Our cases have been managed by different approaches according to usual development of technique. The early cases were managed by laminectomy with or without discectomy while we used anterior discectomy in later cases and then anterior discectomy and fusion with or without cage

The outcome in our cases showed complete recovery in 4 cases $(57.1 \%)$ and incomplete recovery in two cases (28.6\%). One patient $(14.3 \%)$ showed no improvement even after physiotherapy and this finding is quite similar to the outcome in the reported cases in the literature as complete recovery was found in 25 cases (55.6\%) and incomplete recovery in 16 cases $(35.6 \%)$ while only one 4 cases $(8.9 \%)$ showed no significant changes in the neurological condition but there is no significant finding or correlation could be detected between the outcome and duration of symptoms or number of diseased discs

\section{CONCLUSION}

Brown-Sequard syndrome is a rare presentation of cervical disc herniation but it should be considered in our differential diagnosis during the clinical examination. Accurate diagnosis and early spinal cord decompression lead to complete recovery of these cases.

\section{REFERENCES}

1. Antich PA, Sanjuan AC, Girvent FM and Simó JD: High cervical disc herniation and Brown-Séquard syndrome. A case report and review of the literature. J Bone Joint Surg $\mathrm{Br}$ 81(3): 462-463, 1999

2. Borm $\mathrm{W}$ and Bohnstedt $\mathrm{T}$ : Intradural cervical disc herniation. Case report and review of the literature. J Neurosurg 92(2): 221-224, 2000

3. Choi K B, Lee DC, Chung DJ, Lee SH: Cervical disc herniation as a cause of Brown Sequard syndrome; J Korean Neurosurg Soc 46(5):505-510, 2009

4. Clatterbuck RE, Belzberg AJ and Ducker TB: Intradural cervical disc herniation and Brown Sequard syndrome. Report of three cases and review of the literature. J Neurosurg 92(2): 236-240, 2000

5. Eisenberg RA, Bremer AM, Northup HM: Intradural herniated cervical disk. A case report and review of the literature. AJNR 7(3): 492-494, 1986

6. Finelli PF, Leopold N and Tarras S: Brown-Sequard Syndrome and herniated cervical disc. Spine (Phila Pa 1976); 17(5): 598-600, 1992

7. Fujimoto A, Matsumura A, MarunoT, Yasuda S, NoseT:Cervical spondylosis with thoracic level Brown-Séquard syndrome. J Clin Neurosci 11(8): 898-900, 2004

8. Iwamura Y, Onari K, Kondo S, Inasaka R, Horii H: Cervical intradural disc herniation. Spine (Phila $\mathrm{Pa}$ 1976) 26(6): 698-702, 2001 
9. Kelley LA: In neck to neck competition are women more fragile? Clin Orthop Relat Res 372:123-130, 2000

10. Kim JT, Bong HJ, Chung DS, Park YS: Cervical disc herniation producing acute brown-sequard syndrome. J Korean Neurosurg Soc 45(5):312-314, 2009

11. Kobayashi $N$, Asamoto $S$, Doi $H$, Sugiyama H: Brown-Sèquard syndrome produced by cervical disc herniation: Report of two cases and review of the literature. Spine J 3(6):530-533, 2003

12. Kohno M, Takahashi H, Yamakawa K, Ide K, Segawa H: Postoperative prognosis of Brown-Séquard-type myelopathy in patients with cervical lesions. Surg Neurol 51:241-246, 1999

13. Kulkarni V, RajshekharV, Raghuram L: Accelerated spondylotic changes adjacent to the fused segment following central cervical corpectomy: Magnetic resonance imaging study evidence. J Neurosurg 100(1): 2-6, 2004

14. Lee J K, Kim YS, Kim SH: Brown-Sequard syndrome produced by cervical disc herniation with complete neurologic recovery: Report of three cases and review of the literature. Spinal Cord 45(11), 744-748, 2007

15. Marchiori DM, Henderson CN: A cross-sectional study correlating cervical radiographic degenerative findings to pain and disability. Spine (Phila Pa 1976), 21(23):2747-2751, 1996

16. Mastronardi L, Ruggeri A: Cervical disc herniation producing Brown-Sequard syndrome: case report. Spine (Phila Pa 1976); 29(2):E28-31, 2004

17. Radhakrishnan K, Litchy WJ, O'Fallon WM, Kurland LT: Epidemiology of cervical radiculopathy. A population-based study from Rochester, Minnesota, 1976 through 1990. Brain 117 (2):325-335, 1994

18. Roda JM, Gonzalez C, Blázquez MG, Alvarez MP, Argüello C: Intradural herniated cervical disc. Case report. J Neurosurg 57(2):278-280, 1982.

19. Rumana CS, Baskin DS: Brown-Sequard syndrome produced by cervical disc herniation: Case report and literature review. Surg Neurol 45(4):359-361, 1996
20. Rustagi T, Badve S, Maniar H, Parekh A: Cervical disc herniation causing brown-séquard's syndrome: $A$ case report and literature review. Case Reports in Orthopedics, 2011: 1-6, 2011

21. Salemi G, Savettieri G, Meneghini F, Di Benedetto $M E_{,}$ Ragonese P, Morgante L Reggio A, Patti F, Grigoletto F, Di Perri R:Prevalence of cervical spondylotic radiculopathy: A doorto-door survey in a Sicilian municipality. Acta Neurol Scand 93(2-3):184-188, 1996

22. Sani S, Boco T, Deutsch H: Cervical stenosis presenting with acute Brown-Séquard syndrome. Spine (Phila Pa 1976) 30: E481-E483, 2005

23. Sayer FT, Vitali AM, Low HL, Paquette S, Honey CR: BrownSèquard syndrome produced by $\mathrm{C} 3-\mathrm{C} 4$ cervical disc herniation: $A$ case report and review of the literature. Spine (Phila Pa 1976) 33(9):E279-282, 2008

24. Schneider SJ, Grossman RG, Bryan RN: Magnetic resonance imaging of transdural herniation of a cervical disk. Surg Neurol 30(3):216-219, 1988

25. Schoenfeld AJ, George AA, Bader JO, Caram PM: Incidence and epidemiology of cervical radiculopathy in the United States military: 2000 to 2009. J Spinal Disord Tech 25(1): 17-22, 2012

26. Urrutia J, Fadic R: Cervical disc herniation producing acute Brown-Sequard syndrome: Dynamic changes documented by intraoperative neuromonitoring. Eur Spine J 21(4): S418-421, 2012

27. Wang $\mathrm{CH}$,Chen $\mathrm{CC}$ and Cho CD: Brown-Sequard syndrome caused by cervical disc herniation. Mid Taiwan J Med 11: 62-66, 2006

28. Yeung J, Johnson J, Karim A: Cervical disc herniation presenting with neck pain and contralateral symptoms: A case report. Journal of Medical Case Reports 6:166, 2012

29. Yokoyama K, Masahiro Kawanishi M, Yamada M Kuroiwa T: Cervical disc herniation manifesting as a Brown-Sequard syndrome. J Neurosci Rural Pract 3(2):182-183, 2012 